Dansk Ultralyddiagnostisk Selskab

\title{
Fremgang for dansk ultralydforskning
}

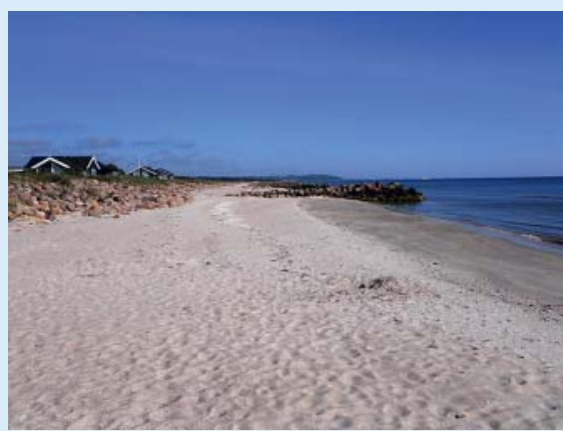

- Fig. 1 Danish beach 2017.

Jeg håber at I alle har haft en god sommerferie. Der har ikke været nogle møder i DUDS i sommerferien og der er derfor ikke mange nyheder. I den kølige sommer med god plads på stranden ( $>$ Fig. 1), der har derfor været tid til at se lidt på dansk ultralyd gennem de sidste par dekader. I PubMed findes der 6746 hits, når man søger på ultralyd og dansk affiliation over cirka de sidste 20 år. Søgestrengen der er anvendt er som følger: ( ( ((ultrasound OR sonography OR ultrasonography)) AND Denmark[Affiliation])) AND ("1996/01/01"[Date - Publication]: "2016/12/31"[Date - Publication])) NOT 2017. Det er ikke sikkert at alle artikler er med, men når der foretages en opdeling på de enkelte år, kan man få et indtryk af den tidsmæssige udvikling. På 20 år er der sket næste en fem dobling af antallet af danske publikationer med 152i 1996 og 784i 2016. Udviklingen kan ses på > Fig. 2. Flere af publikationerne er ikke rent danske, men har måske en eller to danske forfattere. Til gengæld er alle specialer inkluderet og ingen dubletter med kun søgning på PubMed. Der kan være artikler, der ikke er med i opgørelsen, da der ikke er søgt i EMBASE og der kommer heller ikke hit, hvis kun ordret Doppler er med i abstractet, uden ordene ultrasound OR sonography OR ultrasonography. Denne opgørelse er ikke et videnskabeligt arbejde efter et PRISMA flow chart,

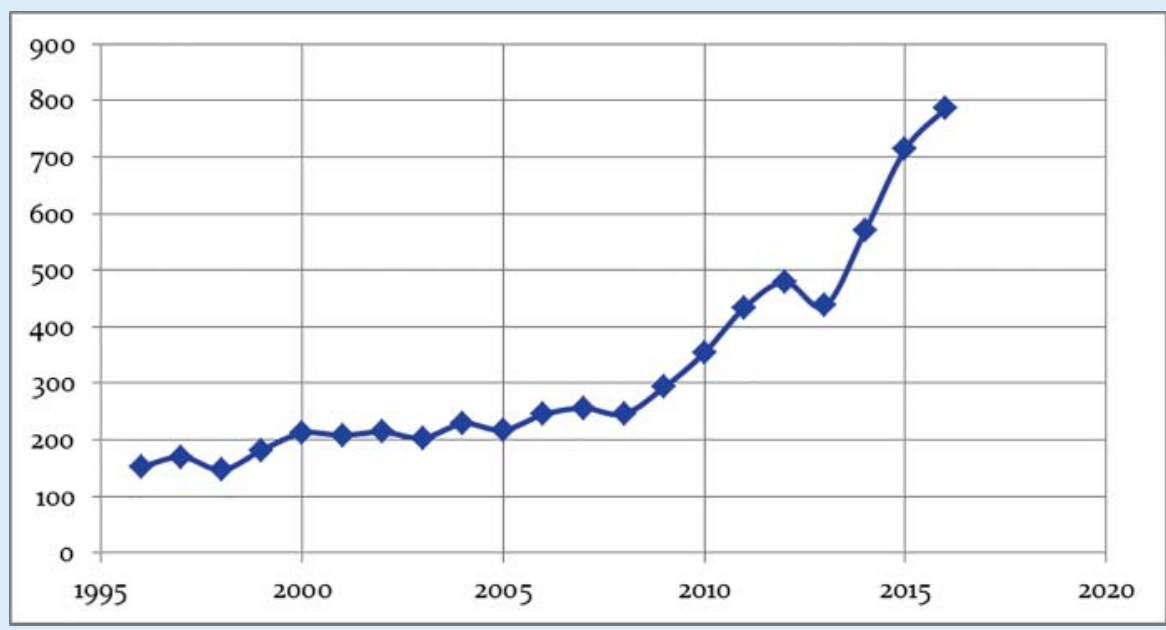

- Fig. 2 Danish ultrasound publications. 1996-2016.

\section{- Fremtidige møder i 2017:}

22. - 24. September 2017 EUROSON 2017 LJUBLJANA, Slovenien

27. - 29. September 2017 DUDS 21. Kursus i Muskeloskeletal ultralyd. Hvidovre Hospital

13. - 17. Oktober $2017 \quad$ WFSUMB 2017 TAIPEI, Taiwan

19. - 20. Oktober 2017 Introductory course of abdominal ultrasound. Stokholm

27. Oktober 2017 Efterårs møde DUDS, OUH, Odense

16. - 17. November 2017 Masterclass course in Transrectal Ultrasonography, Svendborg

1. - 3. November 2017 DUDS Basis kursus. Herlev Hospital

22. - 23. Januar $2018 \quad$ Kursus i muskoloskeletal ultralyd, Skejby Sygehus, Aarhus

24. Januar 2018 Årsmøde, DUDS, HC Andersen Radisson, Odense

16. April 2018 Intro-kursus i akut abdominal ultralydskanning, RH, København

bibliotekaren havde tillige sommerferie. Man kan fra omkring 2008 se en tydelig stigning i antallet af danske artikler omhandlende ultralyd. Søges der på ordret elastography blandt de 6746 danske ultralyd artikler kommer der kun74 hit, så det er nok ikke det der kan forklare hele udviklingen. Der kan derimod være tale om, at der er kommet flere PhD studerende samt at ultralyddiagnostik er vokset i flere specialer. Tak til alle der har bidraget med den øgede forskning, håber den positive udvikling fortsætter og flere af de danske forskere melder sig in i DUDS, gerne med fremlæggelse af de nye resultater til DUDS møder, således at flere kan blive inspireret.

Med venlig hilsen

Søren R. Rafaelsen 